\title{
Influence of herbaceous and woody competition on white pine regeneration in a uniform shelterwood
}

\author{
by Douglas G. Pitt ${ }^{1,2}$, Andrée Morneault ${ }^{3}$, William C. Parker ${ }^{4}$, Len Lanteigne ${ }^{5}$, Michael K. Hoepting ${ }^{1}$ and Al Stinson ${ }^{3}$
}

\begin{abstract}
We investigated the effects of herbaceous and woody vegetation control on the survival and growth of planted and natural eastern white pine (Pinus strobus L.) seedlings through six growing seasons following a uniform shelterwood regeneration harvest on two independent sites. Subsequent to chain scarification, white pine seedlings were planted at 2-m spacing, augmenting natural regeneration (full stocking and $>3000$ seedlings per ha). Herbaceous vegetation control involved the suppression of grasses, forbs, ferns, and low shrubs, and was maintained for zero, two, or four growing seasons after planting. Woody control involved the removal of all tall shrubs and deciduous trees, and was conducted at the time of planting, at the end of the second or fifth growing seasons, or not at all. White pine seedling growth responded positively to increased duration of herbaceous vegetation control and negatively to delayed woody control. Maximum growth was not realized unless both types of vegetation were suppressed. During the first six growing seasons, the height growth of planted pine was more than twice that of naturally regenerating pine, regardless of tending regime. The study suggests that successful white pine regeneration may be achieved by thinning from below to allow $50 \%$ to $60 \%$ of full sunlight in the understory, followed by the proactive, early suppression of woody and herbaceous vegetation to maintain optimum light levels and reduce competition for soil moisture and nutrients.
\end{abstract}

Key words: eastern white pine (Pinus strobus L.), trembling aspen (Populus tremuloides Michx.), red maple (Acer rubrum L.), uniform shelterwood; competition, vegetation management, silviculture

\section{RÉSUMÉ}

Nous avons étudié les effets du contrôle de la végétation herbacée et ligneuse sur la survie et la croissance de semis plantés et naturels de pin blanc (Pinus strobus L.) au cours des six années de croissance qui ont suivi une exploitation selon un mode de régénération par coupes progressives uniformes sur deux sites indépendants. À la suite d'un scarifiage par chaîne, des semis de pin blanc ont été plantés selon un espacement de $2 \mathrm{~m}$ pour accroître la régénération naturelle (densité relative complète et $>3000$ semis par ha). Le contrôle de la végétation herbacée comportait la suppression des graminées, des plantes herbacées, des fougères et des arbrisseaux de faible taille et a été effectué l’année même de la plantation, deux ans ou quatre ans après. Le contrôle de la végétation ligneuse comportait la coupe de tous les arbrisseaux de grande taille et des feuillus et a été réalisé au moment de la plantation, à la fin de la seconde ou de la cinquième année de croissance ou pas du tout. La croissance des semis de pin blanc s’est avérée être positive selon la durée accrue de contrôle de la végétation herbacée, mais elle a été négative dans le cas du contrôle retardé de la végétation ligneuse. Le maximum de croissance n’a été atteint que lorsque les deux types de contrôle avaient été effectués. Au cours des six premières années de développement, la croissance en hauteur était près du double de celle des pins constituant la régénération naturelle, peu importe les traitements de contrôle. L'étude indique qu'une régénération réussie en pin blanc peut être réalisée en effectuant une éclaircie par le bas afin de permettre un ensoleillement complet de $50 \%$ à $60 \%$ du sous-étage, suivie d'une suppression planifiée et hâtive de la végétation ligneuse et herbacée afin de maintenir des niveaux optima d'ensoleillement et réduire la compétition pour l’accès à leau et aux éléments nutritifs contenus dans le sol.

Mots clés : pin blanc (Pinus strobus L.), peuplier faux-tremble (Populus tremuloides Michx.), érable rouge (Acer rubrum L.), coupes progressives uniformes, compétition, contrôle de la végétation, sylviculture

\footnotetext{
${ }^{1}$ Canadian Wood Fibre Centre, Canadian Forest Service, 1219 Queen St. E., Sault Ste. Marie, Ontario P6A 2E5.

${ }^{2}$ Corresponding author. E-mail: dpitt@NRCan.gc.ca.

${ }^{3}$ Southcentral Science and Information Section, Ontario Ministry of Natural Resources, 3301 Trout Lake Rd., North Bay, Ontario P1A 4 L7.

${ }^{4}$ Ontario Forest Research Institute, Ontario Ministry of Natural Resources, 1235 Queen Street East, Sault Ste. Marie, Ontario P6A 2E5.

${ }^{5}$ Canadian Wood Fibre Centre, Canadian Forest Service, P.O. Box 4000, Fredericton, New Brunswick E3B 5P7
} 


\section{Introduction}

Early efforts to manage and regenerate white pine (Pinus strobus L.) using the clearcut silvicultural system and plantations have typically yielded highly variable results due to growth and survival losses from competition with herbaceous and woody vegetation, white pine blister rust (Cronartium ribicola J.C. Fisch.) infection, and/or white pine weevil (Pissodes strobi Peck.) attack (Hosie 1953, Stiell 1985). By the 1970s such regeneration failures prompted experimentation with the uniform shelterwood system (Lancaster and Leak 1978, Hannah 1988) as a means of tailoring white pine management to the ecology of this mid-tolerant species. When combined with site preparation and good vegetation management, the uniform shelterwood system creates a canopy structure and understory environment similar to that believed to be created by the natural fire regime of white pine forests; frequent (20- to 40-year interval) low intensity fires, coupled with comparatively infrequent (150- to 300-year interval) stand-replacing fire (Frelich 2002). When scarification is applied to coincide with mast seed years, shelterwood systems are well suited to establishment and early growth of natural regeneration. In some jurisdictions, uncertainty around the amount and distribution of natural regeneration is mitigated by the underplanting of white pine seedlings (Myketa and McLaughlin 1996, Burgess and Wetzel 2000). Subsequent overstory removal cuts are applied, when stocking, size, and competitive status of pine regeneration is deemed acceptable, to increase understory light availability, maintain sapling height growth, and promote canopy recruitment, while affording continued protection from weevil and blister rust (OMNR 1998). This silvicultural system is now widely used to manage white pine-dominated stands in eastern Canada and the northeastern United States (Lancaster and Leak 1978, Hannah 1988, OMNR 1998).

Despite significant advances in the management of white pine through the uniform shelterwood system, white pine regeneration (natural and/or artificial) success remains frustratingly inconsistent, particularly on fresh-to-moist, highly competitive sites (Hibbs 1982, Chambers 1991). Development of vegetation management strategies for shelterwoods is complicated by the fact that white pine regeneration growing beneath undisturbed or partially harvested canopies experiences competition from both overstory trees and understory vegetation (Shirley 1945, Saunders and Puettmann 1999). The inverse relationship that exists between overstory density and understory growth (Smidt and Puettmann 1998, Krueger and Puettmann 2004) suggests the need to balance residual canopy density with understory vegetation control, such that the understory environment remains unfavourable to weevil and blister rust, but offers adequate resources for competitive pine regeneration growth (Wetzel and Burgess 2001, Krueger and Puettmann 2004, Major et al. 2009). Previous studies have reported on the influence of understory herbaceous and woody competition control on white pine seedling growth beneath partially harvested conifer and hardwood stands (Burgess and Wetzel 2000, 2002; Puettmann and Saunders 2001; Krueger and Puettmann 2004), but the comparative influence of these two forms of vegetation on pine seedling survival and growth in uniform shelterwood systems has not been examined.

To address this information need, we established a field study in 2001 that employs a response-surface design aimed at identifying understory vegetation conditions that favour planted and natural white pine survival and growth in a uniform shelterwood environment. In this study, the timing of woody vegetation control was examined in combination with the duration of herbaceous vegetation control beneath stands at two independent sites-one in northeastern Ontario, the other in central New Brunswick. In this paper, we present the resulting age- 6 response surfaces for white pine survival and growth as guides to the development of more effective and consistent early vegetation management prescriptions for white pine regeneration in a uniform shelterwood. The results of a companion study employing the same experimental design within in an Ontario clearcut were reported previously (Pitt et al. 2009; Parker et al. 2009, 2010).

\section{Methods \\ Experimental design}

In this experiment, we used a response surface design to study the effects of duration of herbaceous vegetation control ( $H$, years) and timing of deciduous woody vegetation control ( $W$, years) on planted white pine survival and growth (Pitt et al. 2009). Herbaceous vegetation control, herein referring to the suppression of grasses, forbs, ferns, and low-shrub vegetation types, was maintained for zero, two, or four consecutive years after planting. Woody vegetation control, involving the removal of all tall-shrubs (species capable of achieving at least $2 \mathrm{~m}$ in height) and deciduous trees, was conducted at the time of planting, at the end of the second or fifth growing seasons, or not yet as of the time of the year- 6 assessment. The measured responses to the resulting treatment combinations (Fig. 1) were used to build a model or "response surface" (Montgomery 2001) to guide forest managers in developing vegetation management prescriptions aimed at optimizing early white pine seedling growth. The advantage of this approach is that it allows for simultaneous interpolation across duration of herbaceous control and the timing of woody control in the optimization of a vegetation management prescription. Since hardwood density may influence the nature of the response surface, three different nominal hardwood densities were studied; 5000, 10 000, and 15000 stems per ha (sph). This range was chosen to reflect the densities that are commonly encountered in white pine regeneration settings following some form of site preparation or scarification. As comparative benchmarks or references, the experiment also included a continuous complete vegetation control treatment during the six growing seasons after planting and a simulated operational "broadcast" release of both woody and herbaceous vegetation after the second growing season.

\section{Study site and installation}

Two recently harvested sites were chosen for this experiment (Table 1). The first is located in the Great Lakes - St. Lawrence Forest Region (Rowe 1972), northeast of North Bay, Ontario, on the Nipissing Forest sustainable forest licence (World Geodetic System (WGS) 84: N4643'50.7'; W79²2'46.1' ). It represents ecosite G033Tt ("dry, sandy: red pine - white pine conifer; tall tree") (OMNR 2009) and is regionally typical of white and red pine-dominated mixedwood sites. Soils are fine loamy sands (first $10 \mathrm{~cm}$ ) over deep, medium- to coarse-textured sands, with an effective rooting depth of about $60 \mathrm{~cm}$ and no signs of mottling or gleying. The 100-year-old fire-origin stand was subjected to the regeneration cut of a uniform 


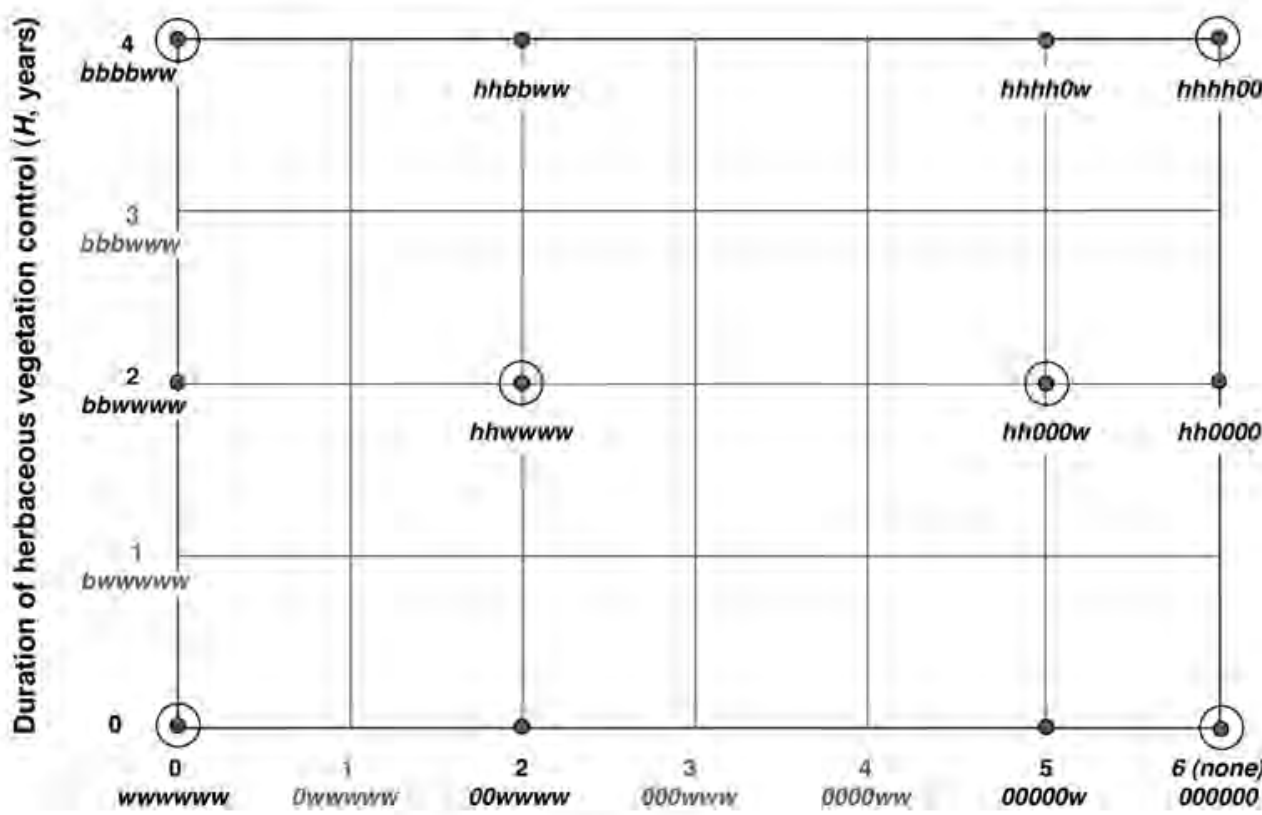

Timing of woody vegetation control $(\mathrm{W})$ (relative to plantation age, years)

- Position of experimental unit on response grid

Replicated experimental unit $(n=3)$

Fig. 1. Response-surface design for studying the effects of competition on white pine establishment and growth. The combinations of duration of herbaceous vegetation control $(H)$ and timing of woody vegetation control $(W)$ lead to 12 treatments. These treatments may be coded in terms of " $O$ " no vegetation control, " $W$ " woody control, " $h$ " herbaceous control, and " $b$ " both woody and herbaceous control, with six characters representing years 1 through 6, respectively. Each of the four corners and center points on the grid are replicated three times (total of 18 experimental units, or plots). The response grid is replicated at three aspen densities (5000, 10000 , and 15000 stems/ha), requiring a total of 60 plots (those with woody control in year 0 being common to each density). Reference treatments include complete vegetation control ( $b b b b b b, n=3$ ) and operational broadcast release (00b000, $n=3 \times 3$ densities). The entire experiment required 72 plots.

shelterwood system in 1999. This cut left a high-quality, mature overstory of white and red pine (Pinus resinosa Ait.), however, many subordinate stems of white spruce (Picea glauca [Moench] Voss), balsam fir (Abies balsamea [L.] Mill.), red maple, and trembling aspen, although marked for harvest, were left standing due to market conditions. In the fall of 2000 , we completed the regeneration cut by thinning the stand from below to emulate what would be conducted under an intensive silvicultural regime. Across the experimental site, the original unharvested stand density was reduced, in total, by $66 \%$, to $132 \mathrm{sph}$, and basal area (BA) by $52 \%$, to $18 \mathrm{~m}^{2} / \mathrm{ha}$ (Table 1). The average diameter $(\mathrm{DBH})$ of the final residual stand was $40 \mathrm{~cm}$, with several stems exceeding $60 \mathrm{~cm}$; species composition was $71 \%$ white pine and $25 \%$ red pine, by BA, all in dominant and codominant trees. For the sake of the experiment, large woody debris and slash were removed from the site to equalize microsite availability for regeneration across the area. The complete area was then chain-scarified with two perpendicular passes in the spring of 2001 (Fig. 2) and a total of $7218-\mathrm{m} \times 18$ - $\mathrm{m}$ treatment plots were subsequently established with 3-m corridors between each. The study's treatments (Fig. 1) were assigned to these plots in a completely randomized fashion.
The second site is located in the Acadian Forest Region (Rowe 1972) of central New Brunswick, $20 \mathrm{~km}$ west of Doaktown (WGS 84: N46 $24^{\prime} 30^{\prime \prime}$; W66 $04^{\prime} 26^{\prime \prime}$ ). This site falls within the New Brunswick Lowlands geomorphological region which has 1600 to 1800 annual growing degree days and $400 \mathrm{~mm}$ to $450 \mathrm{~mm}$ annual precipitation during May to September. Soils are fine, loamy sands $(<10 \mathrm{~cm})$ underlain by formations of grey lithic and feldspathic sandstone (Loucks 1962, Colpitts et al. 1995). An operational regeneration harvest took place in the 100-year-old stand in 1998, leaving a relatively low-quality, mature overstory of eastern white pine (previously damaged by white pine weevil), and scattered representatives of red pine, white birch (Betula papyrifera Marsh.), and red maple (Table 1). The original stand density was reduced by $77 \%$, to $100 \mathrm{sph}$, and BA by $55 \%$, to $18 \mathrm{~m}^{2} / \mathrm{ha}$. The average DBH of the residual stand was $45 \mathrm{~cm}$, with several stems exceeding $60 \mathrm{~cm}$. Scarification was conducted in 1999 with light chains in a single pass and 72 treatment plots were established and assigned the study's 14 treatments in a fashion identical to the ON site.

Plots receiving both deciduous woody and herbaceous vegetation control (b) (Fig. 1) in advance of the first growing season were treated with a broadcast foliar application of 
Table 1. Summary of stand statistics associated with trees removed and left standing post uniform shelterwood regeneration cut at the two study sites. Data were collected from a 100\% tally of the experimental areas (research plots + corridors). Both stands averaged 100 years of age in 2001.

\begin{tabular}{|c|c|c|c|c|c|c|c|}
\hline Site & Species & Status & $\begin{array}{l}\text { No. trees } \\
\text { sampled }\end{array}$ & $\begin{array}{c}\text { Basal area } \\
\left(\mathbf{m}^{2} / \mathbf{h a}\right)\end{array}$ & Stems/ha & $\begin{array}{c}\text { Average } \\
\text { height (m) }\end{array}$ & $\begin{array}{c}\text { Average } \\
\text { DBH }(\mathrm{cm})\end{array}$ \\
\hline \multirow[t]{15}{*}{$\mathrm{ON}$} & white pine & harvested & 427 & 9.7 & 126 & 23 & 29 \\
\hline & red pine & & 273 & 6.5 & 80 & 24 & 30 \\
\hline & aspen & & 115 & 2.7 & 34 & 24 & 31 \\
\hline & white spruce & & 22 & 0.5 & 6 & 23 & 29 \\
\hline & white birch & & 19 & 0.3 & 6 & 16 & 24 \\
\hline & red maple & & 13 & 0.0 & 4 & 12 & 11 \\
\hline & & & 869 & 19.7 & 256 & 23 & 30 \\
\hline & & & - & $-52 \%$ & $-66 \%$ & - & - \\
\hline & white pine & remaining & 318 & 12.7 & 94 & 27 & 40 \\
\hline & red pine & & 109 & 4.6 & 32 & 27 & 42 \\
\hline & aspen & & 18 & 0.6 & 5 & 25 & 37 \\
\hline & white spruce & & 2 & 0.0 & 1 & 24 & 29 \\
\hline & jack pine & & 1 & 0.0 & 0 & 27 & 38 \\
\hline & & & 448 & 18.0 & 132 & 27 & 40 \\
\hline & & Total & 1317 & 37.7 & 388 & 24 & 33 \\
\hline \multirow[t]{13}{*}{$\mathrm{NB}$} & white pine & harvested & 548 & 18.6 & 235 & 21 & 30 \\
\hline & white birch & & 84 & 1.4 & 36 & 17 & 22 \\
\hline & red maple & & 118 & 1.1 & 51 & 13 & 16 \\
\hline & red pine & & 4 & 0.1 & 2 & 16 & 19 \\
\hline & white spruce & & 10 & 0.1 & 4 & 15 & 17 \\
\hline & & & 764 & 21.3 & 328 & 19 & 27 \\
\hline & & & - & $-55 \%$ & $-77 \%$ & - & - \\
\hline & white pine & remaining & 204 & 16.2 & 87 & 26 & 47 \\
\hline & red maple & & 14 & 0.5 & 6 & 19 & 31 \\
\hline & white birch & & 12 & 0.5 & 5 & 21 & 36 \\
\hline & red pine & & 4 & 0.3 & 2 & 24 & 45 \\
\hline & & & 234 & 17.5 & 100 & 25 & 45 \\
\hline & & Total & 998 & 38.8 & 428 & 20 & 31 \\
\hline
\end{tabular}

glyphosate during early September 2001 (year 0). A Solo ${ }^{\circ}$ backpack sprayer was used for these applications, equipped with an $18^{\prime \prime}$ wand and 8004 nozzle, delivering a 3\% solution of Vision ${ }^{\circledR}$ herbicide. Plots receiving herbaceous-only vegetation control $(h)$ were similarly treated, but with care taken to avoid any contact with aspen, red maple, and other deciduous tree species on the site. Plots receiving initial woody-only vegetation control $(w)$ were treated at the end of the 2001 growing season with a basal bark treatment (streamline method) and the herbicide Release ${ }^{\circ}$ (25\% product mixed in mineral oil, applied with very low pressure, directly to the lower $30 \mathrm{~cm}$ of target stems with a backpack sprayer equipped with an $18^{\prime \prime}$ wand and a SS1502 nozzle).

All plots were planted at 2-m spacing during May of 2002. In ON, Multipot 67, 1-0 containerized white pine seedlings were used, averaging $10 \mathrm{~cm}$ in height and $2.4 \mathrm{~mm}$ in stem diameter, measured $5 \mathrm{~cm}$ above ground line (AGL). In NB, Jiffy 36 seedlings were used, averaging $10 \mathrm{~cm}$ in height and 2.5 $\mathrm{mm}$ in stem diameter at the time of planting. To augment natural hardwood densities and ensure uniform distributions across the plots, containerized aspen and red maple seedlings (Multipot 67 in ON, Jiffy 36 in NB; dormant 1-0 stock) were planted, where necessary, in plots that had not yet received woody vegetation control. Across the experiments, planted hardwood stems represented a very small proportion of overall hardwood densities $(<5 \%)$; bias in planting location was avoided by using plot maps of randomly generated planting locations to guide tree positions within each plot.

On complete vegetation control plots and herbaceous-only control plots, vegetation control was maintained during each growing season dictated by the experimental design (Fig. 1) via periodic manual clipping and directed foliar applications of glyphosate $\left(2 \% V_{\text {Vision }}{ }^{\circ}\right)$ at the end of the preceding growing season (late August/ early September). Planted pine were protected with cups or plastic bags, when necessary, to prevent herbicide injury; naturally regenerating pine were avoided wherever possible. On plots receiving later woody-only control, basal bark treatment was used at the end of the preceding growing season. Once deciduous woody control occurred within the response-surface experiment, either through complete vegetation control or woody-only control, woody control was maintained through subsequent years, as needed, via manual clipping. Plots assigned to the simulated operational release treatment received a broadcast application of glyphosate $(2 \%$ 


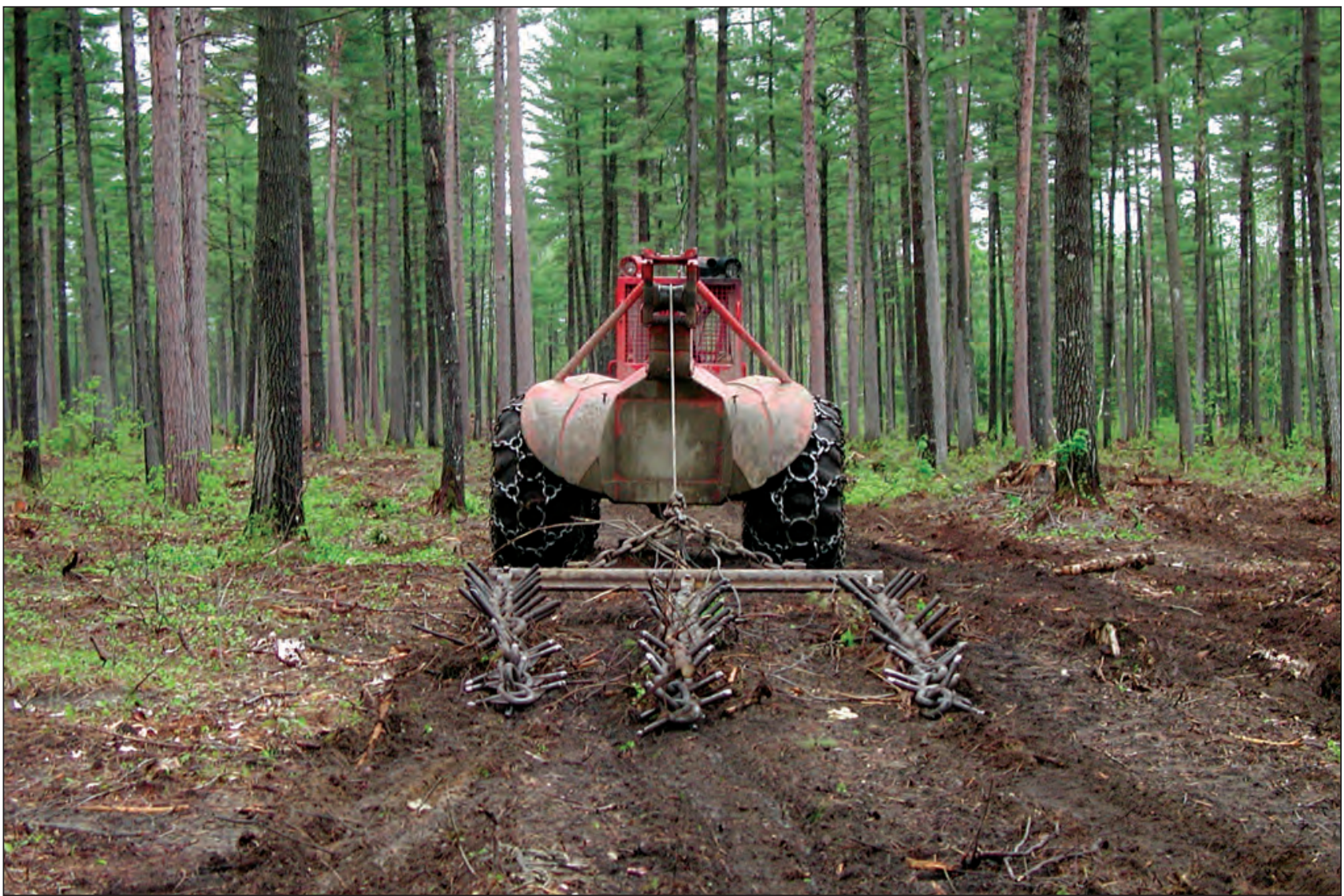

Fig. 2. Ontario uniform shelterwood, immediately following the regeneration cut, and during scarification in spring, 2001. See Table 1 for stand descriptive statistics.

Vision $^{\oplus}$ ) at the end of the second growing season, with no subsequent follow-up treatments or manual clipping.

At the beginning of the second growing season, aspen and other deciduous tree species on the plots were thinned to the target densities of 5000, 10000 , and 15000 sph for plots previously stratified as low, medium, and high density. Hand shears were used for this and bias in stem selection was avoided by retaining those stems closest to the mapped positions of randomly generated tree locations for each density. This process was repeated each spring, as needed, to maintain the plots as close as possible in the target density classes.

To avoid reduction in white pine sample size due to fatal blister rust infections, all planted pine were treated with a single application of triadimefon during mid July of each of the first five growing seasons. The fungicide Bayleton ${ }^{\circ}$ was mixed with water at a rate of $300 \mathrm{mg}$ active per $\mathrm{L}$, each seedling being sprayed to wet with a Solo ${ }^{\circ}$ backpack sprayer, equipped with an $18^{\prime \prime}$ wand and 8004 nozzle.

\section{Field measurements}

Within each treatment plot, we established a centrally located $10-\mathrm{m} \times 10-\mathrm{m}$ measurement plot. The 25 planted pine within each of these measurement plots ( 5 trees $\times 5$ trees) were identified with a pin-mounted, numbered aluminum tag. At the end of each of the first six growing seasons, surviving trees were measured for total height (HT; ground line to the tip of the tallest bud; $\mathrm{cm}$ ) and stem diameter (D5; $5 \mathrm{~cm}$ AGL; mm). At the end of the sixth growing season, a similar set of meas- urements were made on a single naturally regenerated white pine, of the best health and form (usually, but not necessarily the largest tree), situated within each of the $162-\mathrm{m} \times 2$-m cells bound by the 25 planted pine in the measurement plot. These sixteen cells were also used to calculate natural regeneration stocking for the plot; a cell being considered stocked if it contained a living white pine seedling, and not stocked otherwise:

$$
\text { [1] stocking }=\frac{\text { no. stocked cells }}{16} \times 100 \%
$$

Cover of vegetation within the measurement plots was estimated from five 2-m $\times 2$-m subplots during peak growing season (mid-August) of each of the first six years. Subplot centres were randomly located within each measurement plot and permanently identified. Cover and cover-weighted height were recorded for deciduous trees, tall shrubs, low shrubs, forbs, ferns, grasses, planted pine, and other conifers (including naturally regenerated pine). Cover assessments were facilitated by placing two 2-m lengths of graduated plastic pipe at right angles to each other over the subplot center, and visually estimating the portion of the subplot ground surface occupied by the vertical projection of the plant crown(s), to the nearest $5 \%$. Trace amounts of cover were assigned a value of $1 \%$. For each vegetation group (except grass/sedge) in each subplot, the proportion of group cover occupied by the dominant five species was also recorded.

On July 17, 2006 (year 5), a damaging wind storm swept through northeastern $\mathrm{ON}$, causing widespread blowdown in 
many areas, including the Nipissing Forest. The overstory of a 1-ha portion of the stand in which our study was located completely blew down, affecting eight of the study's 72 plots. Although some of the regenerating pine and non-crop vegetation in these plots was damaged by falling trees, we chose to continue to measure the plots "as is", rather than reduce sample size by removing these plots in the year- 6 analyses.

To estimate average overstory canopy transmittance, understory light conditions were measured at random treatment plot locations across each site (ON, $n=36$; NB, $n=43$ ). Following peak leaf out in July of a single growing season, on a day with uniformly overcast skies, photosynthetic photon flux density (PFD) levels were measured near plot center, above the canopy of any understory vegetation present using a LI-191SB line quantum sensor (LICOR, Inc, Lincoln, NE, USA). A single LI-190SA quantum sensor and LI-1000 microdatalogger (LICOR, Inc, Lincoln, NE, USA) were placed in a nearby opening to provide parallel, instantaneous measurements of above canopy PFD. The ratio of below- to above-canopy PFD for each location provided an estimate of mean percent PFD transmitted through the shelterwood canopy (i.e., canopy transmittance expressed as a percentage of full sunlight) (Messier and Puttonen 1995).

\section{Statistical analyses}

Data for the planted white pine were analysed using a response-surface approach, based on a second-order polynomial model (Montgomery 2001), using PROC RSREG of the $\mathrm{SAS}^{\circledast}$ system (SAS Institute Inc. 2004). These analyses were used to determine the nature and magnitude of the effects of duration of herbaceous vegetation control, timing of woody control, and their interaction, on crop tree response. To do this, the full model [2] was reduced to contain only statistically significant factors $(p<0.10)$, using a process of backward elimination:

[2] $Y=\beta_{0}+\beta_{1} D E N S I T Y+\beta_{2} W+\beta_{3} W^{2}+\beta_{4} H+\beta_{5} H^{2}+\beta_{6} W H+\varepsilon$,

where $Y$ is pine response, $\beta_{0} \ldots \beta_{6}$ are parameters to be estimated, DENSITY is regenerating hardwood stem density, $W$ and $H$ are as previously defined, and $\varepsilon$, are random errors. Where necessary to stabilize variance in these regressions, data were weighted by the inverse of the variance of the response variable, estimated from a linear regression of the variances calculated for repeat observations, on values of $H$ (Draper and Smith 1998). Repeat observations on the response surface (Fig. 1) were used to test model [2] for lack of fit $(p<0.10)$ in each case (Montgomery 2001). Response variables used in model [2] were treatment plot means for sixth-year white pine survival, and measures of growth, including stem diameter (D5), height (HT), and stem volume index $(S V I)$, estimated for each stem as:

$$
\text { [3] } \operatorname{SVI}\left(\mathrm{cm}^{3}\right)=\frac{\pi \times D 5(\mathrm{~mm})}{3 \times 400} \times H T(\mathrm{~cm})
$$

To study the separate effects of herbaceous- and woodycontrol (i.e., on their own, in the absence of each other) and address hypotheses related to the reference treatments, planted white pine responses were further subjected to analysis of variance (ANOVA). Contrasts were used to identify lin- ear and quadratic (i.e., proportional and disproportional) trends related to the individual levels of $H$ and $W$ (specifically, 000000, hh0000, hhhh00; and 000000, 00000w, 00wwww, $w w w w w w)$, as well as test for increases in tree size from four and six years of complete vegetation control ( $b b b b w w$ vs. $b b b b b b$ ), and differences between broadcast release and two years of herbaceous control plus second-season woody control (00b000 vs. $h h w w w w)$. Similar analyses were conducted for the naturally regenerated pine response variables. In all the above analyses, hardwood DENSITY was used as a blocking variable and model residuals were examined to verify that the assumptions of homogeneity of variance and normality were met; data transformations were not necessary.

\section{Results}

Understory light and vegetation dynamics

Canopy transmittance values averaged $54.9 \%$ at the $\mathrm{ON}$ site and $58.6 \%$ at the NB site (Fig. 3). Residual tree spacing and the size of individual canopy gaps were more spatially uniform at the ON site than at the NB study site. This was reflected in a smaller standard deviation $(\mathrm{SD}=7.6 \%)$ and slightly narrower range $(41.4 \%$ to $82.4 \%)$ in canopy transmittance values measured at the $\mathrm{ON}$ site than at the NB shelter-

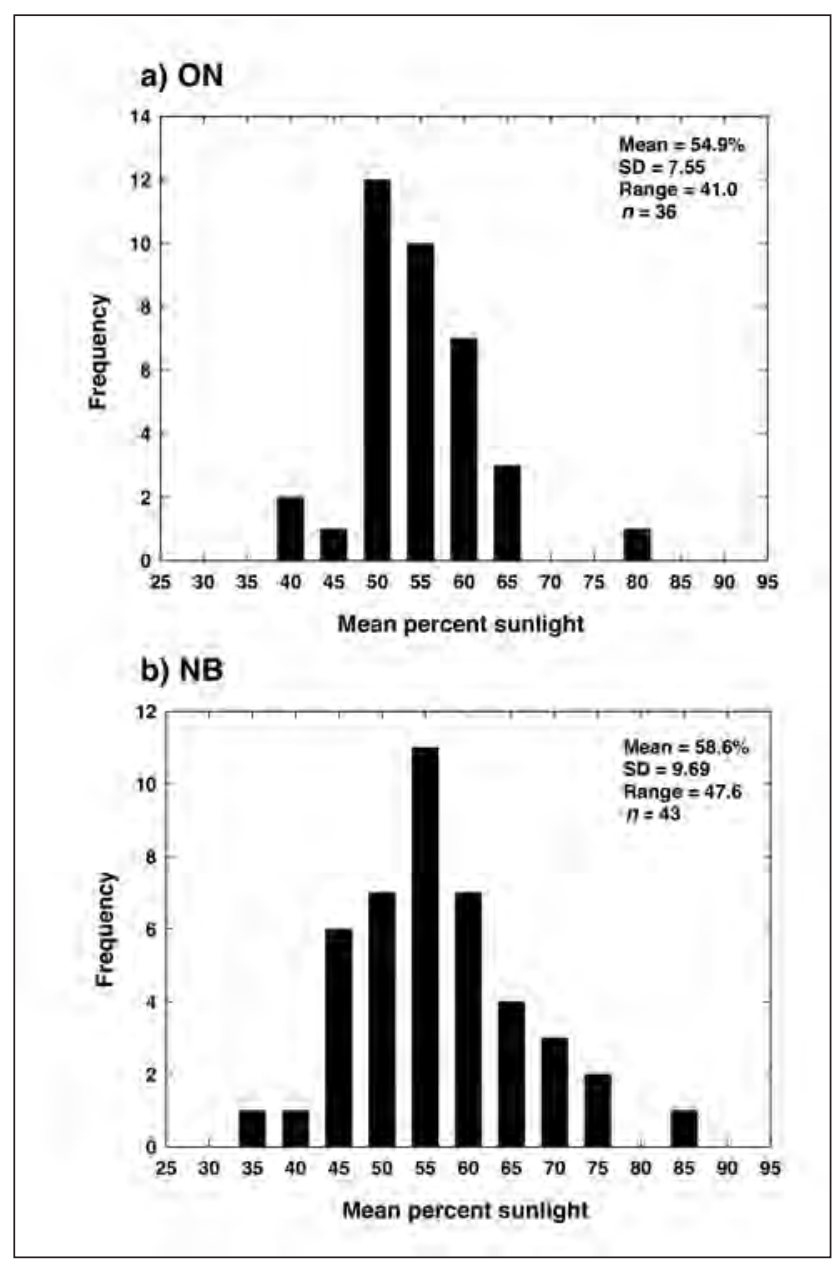

Fig. 3. Distribution of canopy transmittance (percentage of incident sunlight) from $n=36$ samples at the ON site (a) and $n=$ 43 samples at the NB site (b) 
Table 2. Growth statistics for planted white pine at the end of the sixth growing season. Treatment codes are defined in Fig. 1. Treatment means have been averaged over the three hardwood densities studied.

\begin{tabular}{|c|c|c|c|c|c|c|}
\hline Site & Treatment Code & $\begin{array}{c}n \\
\text { plots }\end{array}$ & $\begin{array}{c}\text { Mortality } \\
(\%)\end{array}$ & $\begin{array}{l}\text { Diameter } \\
(\mathbf{m m})\end{array}$ & $\begin{array}{c}\text { Height } \\
(\mathrm{cm})\end{array}$ & $\begin{array}{l}\text { Stem volume } \\
\text { index }\left(\mathrm{cm}^{3}\right)\end{array}$ \\
\hline \multirow[t]{22}{*}{ ON } & 000000 & 9 & 1 & 13 & 119 & 73 \\
\hline & $00000 w$ & 3 & 9 & 15 & 115 & 80 \\
\hline & $00 w w w w$ & 3 & 0 & 20 & 140 & 180 \\
\hline & $w w w w w w$ & 3 & 5 & 20 & 139 & 177 \\
\hline & hhoooo & 3 & 0 & 18 & 139 & 141 \\
\hline & hhhh00 & 9 & 3 & 19 & 140 & 162 \\
\hline & hhooow & 9 & 6 & 22 & 154 & 242 \\
\hline & $h h w w w w$ & 9 & 4 & 35 & 177 & 711 \\
\hline & hhhhow & 3 & 3 & 23 & 129 & 240 \\
\hline & hhbbww & 3 & 1 & 35 & 185 & 699 \\
\hline & $b b w w w w$ & 3 & 7 & 30 & 184 & 517 \\
\hline & bbbbww & 3 & 0 & 42 & 199 & 990 \\
\hline & $b b b b b b$ & 3 & 1 & 29 & 164 & 450 \\
\hline & $00 b 000$ & 9 & 12 & 29 & 154 & 408 \\
\hline & \multicolumn{2}{|c|}{ mean } & 4 & 24 & 151 & 344 \\
\hline & \multicolumn{2}{|c|}{ RMSE } & 6 & 5 & 23 & 179 \\
\hline & \multicolumn{2}{|c|}{$W$ linear } & 0.07 & 0.24 & 0.69 & 0.69 \\
\hline & \multicolumn{2}{|c|}{$W$ quadratic } & 0.83 & 0.60 & 0.81 & 0.81 \\
\hline & \multicolumn{2}{|c|}{$H$ linear } & 0.56 & 0.03 & 0.06 & 0.29 \\
\hline & \multicolumn{2}{|c|}{$H$ quadratic } & 0.58 & 0.51 & 0.50 & 0.84 \\
\hline & \multirow{2}{*}{\multicolumn{2}{|c|}{$\begin{array}{l}\text { Complete control } \\
\text { Broadcast release }\end{array}$}} & 0.48 & 0.99 & 0.99 & 0.99 \\
\hline & & & $<0.01$ & $<0.01$ & 0.03 & $<0.01$ \\
\hline \multirow[t]{22}{*}{ NB } & 000000 & 9 & 10 & 16 & 116 & 120 \\
\hline & $00000 w$ & 3 & 11 & 16 & 107 & 97 \\
\hline & $00 w w w w$ & 3 & 15 & 18 & 127 & 189 \\
\hline & $w w w w w w$ & 3 & 11 & 19 & 123 & 218 \\
\hline & hhoooo & 3 & 8 & 28 & 156 & 397 \\
\hline & hhhh00 & 9 & 15 & 27 & 158 & 415 \\
\hline & hhooow & 9 & 11 & 30 & 161 & 514 \\
\hline & $h h w w w w$ & 9 & 13 & 37 & 175 & 812 \\
\hline & hhhhOw & 3 & 8 & 34 & 186 & 711 \\
\hline & hhbbww & 3 & 11 & 33 & 161 & 579 \\
\hline & $b b w w w w$ & 3 & 13 & 36 & 177 & 725 \\
\hline & $b b b b w w$ & 3 & 13 & 40 & 176 & 890 \\
\hline & $b b b b b b$ & 3 & 8 & 42 & 179 & 1050 \\
\hline & $00 b 000$ & 9 & 7 & 28 & 148 & 426 \\
\hline & \multicolumn{2}{|c|}{ mean } & 11 & 28 & 153 & 488 \\
\hline & \multicolumn{2}{|c|}{ RMSE } & 8 & 5 & 26 & 256 \\
\hline & \multicolumn{2}{|c|}{$W$ linear } & 0.84 & 0.59 & 0.88 & 0.81 \\
\hline & \multicolumn{2}{|c|}{$W$ quadratic } & 0.48 & 0.99 & 0.90 & 0.95 \\
\hline & \multirow{2}{*}{\multicolumn{2}{|c|}{$\begin{array}{r}H \text { linear } \\
H \text { guadratic }\end{array}$}} & 0.19 & $<0.01$ & $<0.01$ & 0.02 \\
\hline & & & 0.34 & 0.07 & 0.23 & 0.42 \\
\hline & \multicolumn{2}{|c|}{$\begin{array}{r}H \text { quadratic } \\
\text { Complete control }\end{array}$} & 0.40 & 0.61 & 0.92 & 0.45 \\
\hline & \multicolumn{2}{|c|}{ Broadcast release } & 0.10 & $<0.01$ & 0.03 & $<0.01$ \\
\hline
\end{tabular}

wood (SD $=9.7 \%$; range: $38.2 \%$ to $85.8 \%$ ). Throughout the study, we observed little evidence of white pine weevil attack on understory white pine at either site.

Patterns in vegetation cover and height development on the site reflected the study's 14 vegetation-control treatment combinations and the competitive environments they create (data available from the corresponding author upon request). While these data are not integral to the crop-tree analyses presented in this paper, they validate the treatments applied, and may provide important site and stand-condition context for some readers.

\section{Planted white pine response \\ Survival}

By age 6 , planted pine mortality averaged $4 \%$ at the ON site and $11 \%$ at the NB site (Table 2). Mortality was generally not treatment-related $(p \geq 0.07)$, although there was some indication that the broadcast release treatment in ON (00b000) resulted in higher mortality than equivalent response-surface treatments $(p<0.01)$. Since the planted pine were protected during herbicide application, this mortality cannot be attributed to herbicide injury. A lack of treatment differences obviated response surface analyses of the survival data. 


\section{a) ON age-6 stem diameter $(\mathrm{mm}), \mathrm{RMSE}=4.7 \mathrm{~mm}$}

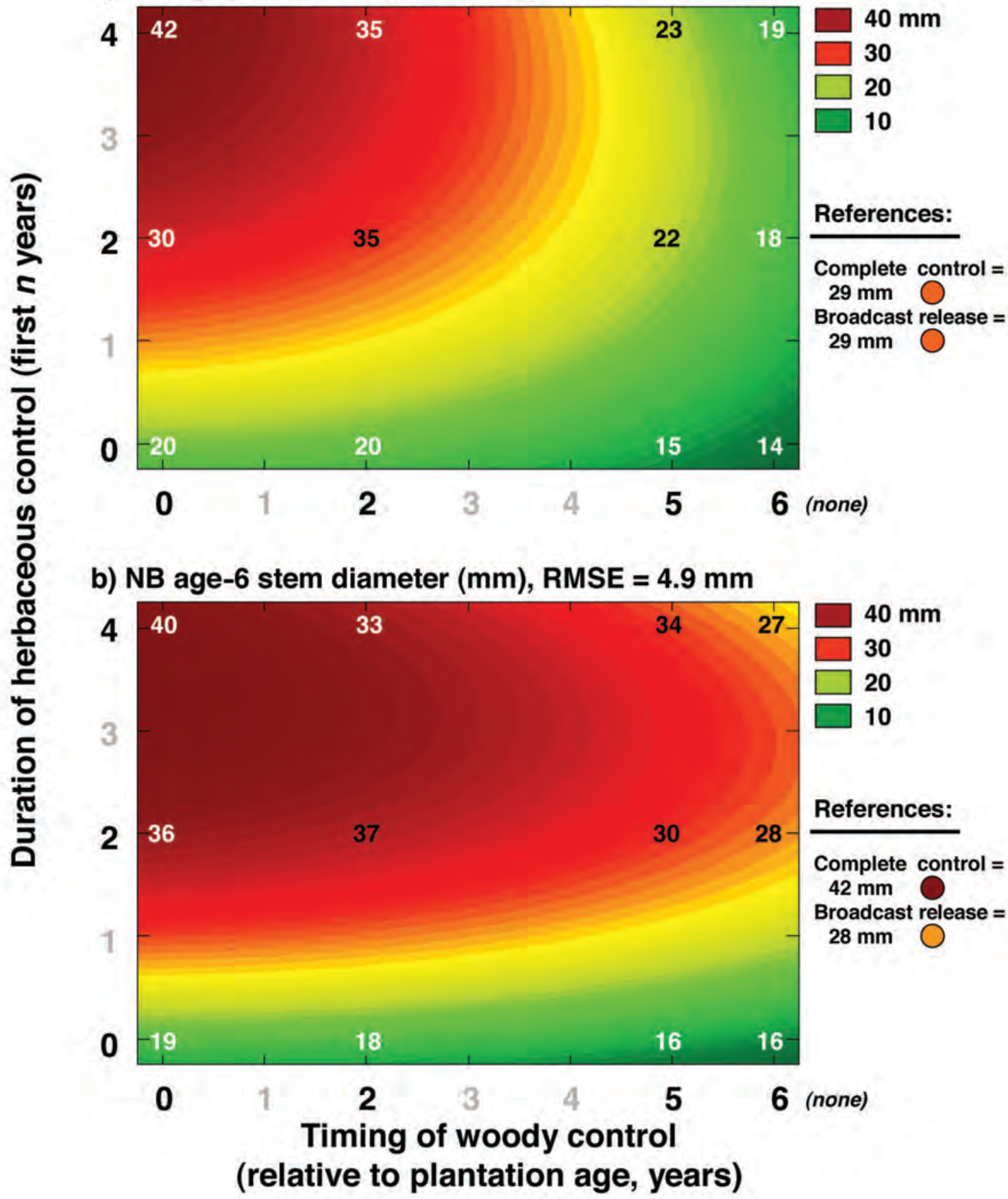

Fig. 4. Two-dimensional representations (contour plots) of the response surfaces outlined in Table 3 for age- 6 stem diameter at the ON (a) and NB (b) sites, respectively ( $n=60$ observations for each). Average values for the response surface and reference treatments are provided.

Stem diameter

Planted white pine stem diameter at age 6 showed positive responses to both woody and herbaceous vegetation control (Fig. 4). In the absence of herbaceous control, the effects of woody control were not particularly strong ( $p \geq 0.24$; Table 2$)$; however, the parameter estimates from model [2] (Table 3) suggest that delays in woody vegetation control resulted in measurably smaller age-6 diameters (e.g., reduction in diameter, $\mathrm{mm}=-0.24 \times W^{2}$ for $\mathrm{ON} ;-0.13 \times W^{2}$ for $\left.\mathrm{NB}\right)$. For example, a delay of two years in ON resulted in a 5\% reduction in stem diameter $(21.46 \mathrm{~mm}-0.96 \mathrm{~mm})$; a delay of five years a $28 \%$ reduction $(21.46 \mathrm{~mm}-6.0 \mathrm{~mm})$. Similar delays in woody vegetation control at the NB site resulted in $3 \%$ to $16 \%$ reductions in stem diameter. 
ザ

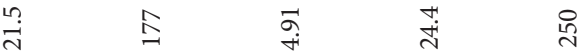

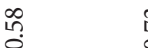

กิ

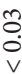

$\stackrel{\infty}{\infty}$

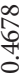

సิำ

శై

तิ่

: ?

in

भे

$\begin{array}{lc}1 & \infty \\ \infty & \infty \\ 0 & \infty \\ 0 & \infty \\ 0 & \infty \\ 0\end{array}$

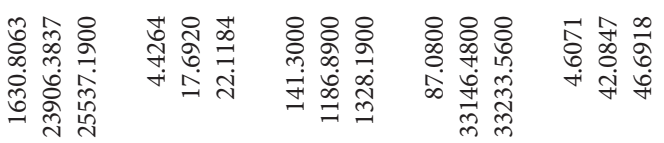

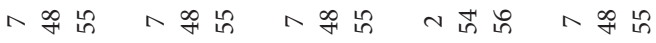

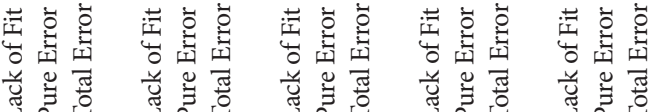

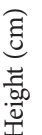

In contrast, herbaceous vegetation control, by itself, was associated with more dramatic increases in stem diameter than woody control alone, particularly at the NB site ( $p \leq 0.03$; Table 2$)$. Parameter estimates from model [2] (Table 3 ) suggest somewhat diminishing returns from increased duration of herbaceous control (increase in diameter, $\mathrm{mm}=$ $8.94 \times H-0.94 \times H^{2}$ for ON; $12.10 \times H-1.80 \times$ $H^{2}$ for NB). Two years of early herbaceous vegetation control resulted in at least a $66 \%$ increase in diameter; four years of control a $98 \%$ increase. At both sites, diameter gains achieved through herbaceous control were reduced as woody control was delayed. This interaction was most apparent at the $\mathrm{ON}$ site (reduction in diameter, $\mathrm{mm}=-0.63 \times W H$ ), where the effects of early herbaceous control were greatly reduced by year 6 in the absence of woody control (Fig. 4a). In NB, the effects of herbaceous control were more persistent through delayed woody control (Fig. $4 \mathrm{~b} ;-0.29 \times W H$ ). Aspen and maple stem density, within the range tested, did not influence these outcomes $(p \geq 0.11)$.

Expressed in terms of untreated planted pine response, the application of both woody and herbaceous vegetation control resulted in the largest increases in planted pine stem diameter. For example, two to four years of herbaceous vegetation control, coupled with woody control by year 2 , resulted in 1.2- to 2.2-fold increases in diameter at the $\mathrm{ON}$ site, and 1.1- to 1.5-fold increases at the NB site. At age 6 , we observed no increase in the diameter of pine subjected to four years, compared to six years, of total competition suppression $(p \geq 0.61)$. In fact, we observed a distinct reduction in the size of trees in plots receiving six years of complete vegetation control (bbbbbb) in ON (Table 2). Trees receiving two years of early herbaceous control plus secondseason woody control exhibited $22 \%$ to $30 \%$ larger stem diameters than those subjected to second-season broadcast release $(p<0.01)$.

\section{Stem height}

Patterns of planted white pine total height at age 6 generally revealed similar responses to those exhibited by stem diameter. Tree height increased in response to both woody and herbaceous vegetation control (Fig. 5). The effects of woody control, alone, were not strong ( $p \geq 0.69$; Table 2$)$, although, parameter estimates from model [2] (Table 3 ) indicate that delays in woody vegetation control resulted in proportionately shorter pine. For example, trees in ON averaged just over $4 \mathrm{~cm}$ shorter for each year that woody control was delayed (reduction in height, $\mathrm{cm}=-4.2 \times W$ ). A delay of two years resulted in a $6 \%$ reduction in stem height $(142.5 \mathrm{~cm}$ $-8.3 \mathrm{~cm}$ ); a delay of five years a $15 \%$ reduction $(142.5 \mathrm{~cm}-20.8 \mathrm{~cm})$. Similar delays in woody vegetation control at the NB site resulted in $4 \%$ to $10 \%$ reductions in stem height.

Herbaceous vegetation control, by itself, was associated with more dramatic increases in stem height than woody control alone, particularly at the 
a) ON age-6 stem height (cm), RMSE $=22 \mathrm{~cm}$

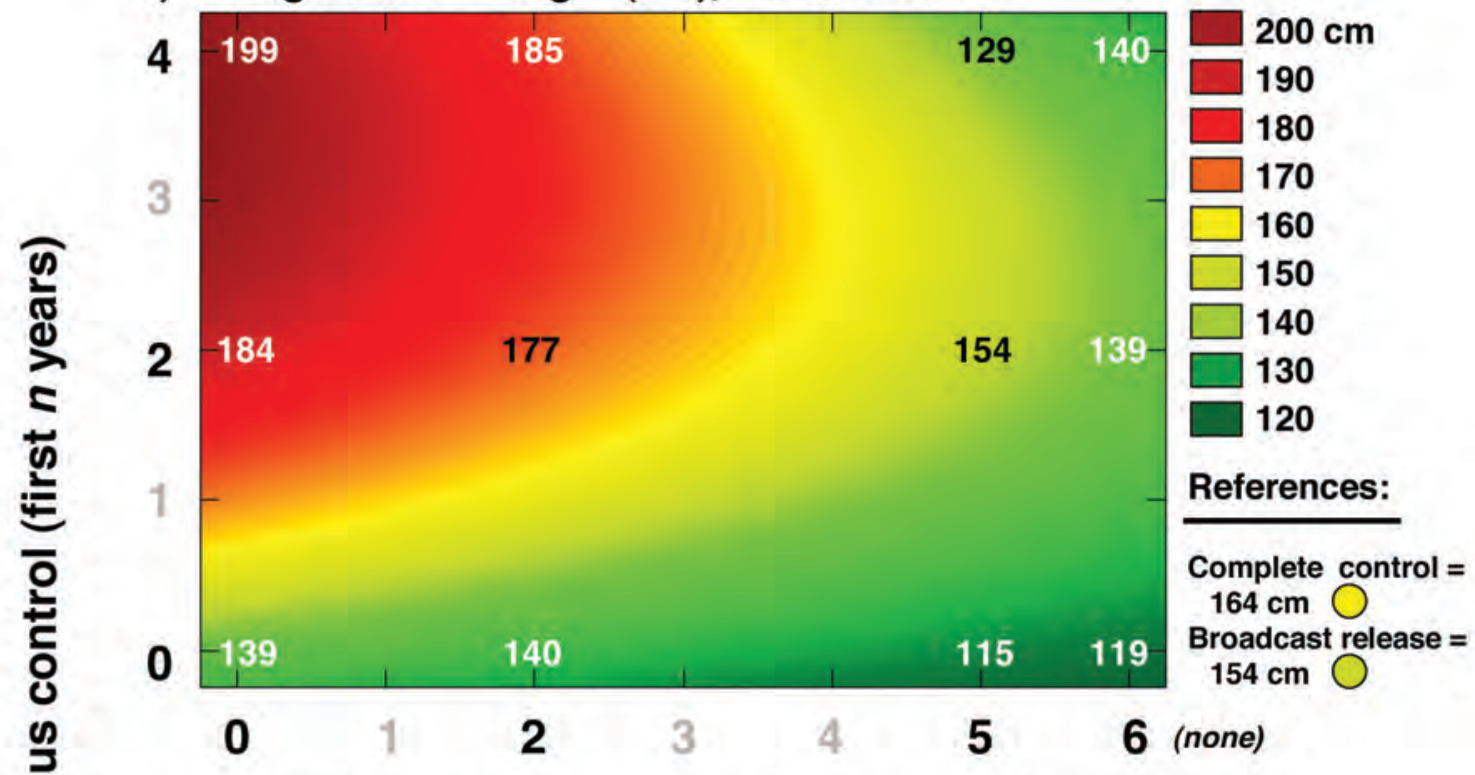

b) NB age-6 stem height (cm), RMSE $=24 \mathrm{~cm}$

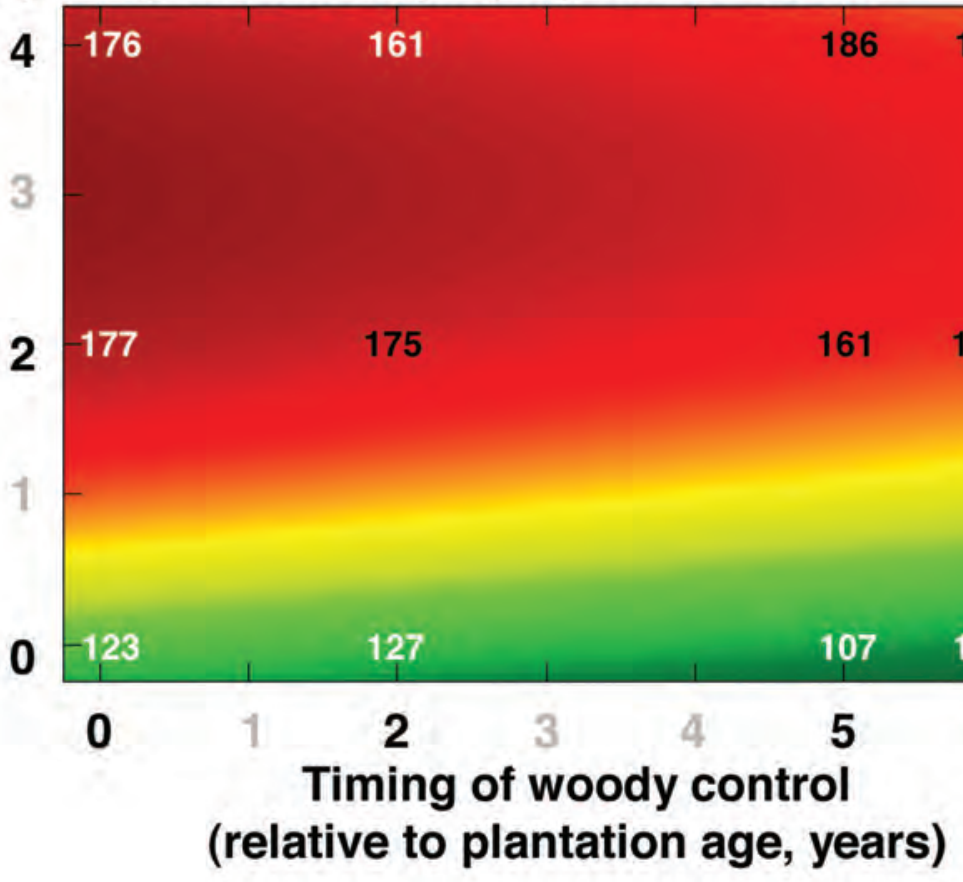

Fig. 5. Two-dimensional representations (contour plots) of the response surfaces outlined in Table 3 for age- 6 stem height at the ON (a) and NB (b) sites, respectively ( $n=60$ observations for each). Average values for the response surface and reference treatments are provided.

NB site $(p \leq 0.06$; Table 2$)$. Parameter estimates from model [2] (Table 3) indicate diminishing returns from increased duration of herbaceous control (increase in height, $\mathrm{cm}=33.2$ $\times H-4.7 \times H^{2}$ for $\mathrm{ON} ; 36.4 \times H-6.0 \times H^{2}$ for NB). Two years of early herbaceous vegetation control resulted in at least a $35 \%$ increase in height; four years of control a $40 \%$ increase. At the $\mathrm{ON}$ site, height gains achieved through herbaceous control were reduced as woody control was delayed (reduction in height, $\mathrm{cm}=-1.7 \times W H$ ). Similar to what was observed with stem diameter in $\mathrm{ON}$, the effects of early herbaceous control were greatly reduced by year 6 in the absence of woody control (Fig. 5). In NB, the effects of herba- 
ceous control persisted strongly through delayed woody control $(H$ linear, $p<0.01)$. Aspen and maple stem density, within the range tested, did not influence these outcomes $(p \geq 0.85)$.

Expressed in terms of untreated planted pine response, the application of both woody and herbaceous vegetation control resulted in the largest increases in planted pine height. For example, two to four years of herbaceous vegetation control, coupled with woody control by year 2 , resulted in $50 \%$ to $70 \%$ increases in height at the ON site, and $40 \%$ to $55 \%$ increases at the NB site. At age 6, we observed no increase in the height of pine subjected to four years, compared to six years, of total competition suppression ( $p \geq 0.92)$. Trees receiving two years of early herbaceous control plus second-season woody control exhibited $15 \%$ to $18 \%$ larger stem heights than those subjected to second-season broadcast release $(p=0.03)$.

\section{Stem volume index}

Since treatment-related patterns in planted pine diameter and height growth were similar, it is not surprising that the integration of both measures in the form of stem volume index did little but accentuate treatment differences already presented (Table 2). The response surfaces derived for stem volume (Table 3) show significant penalties for delayed woody vegetation control $\left(-3.68 \times W^{2} \mathrm{~cm}^{3}\right.$ in $\mathrm{ON} ;-22.5 \times W \mathrm{~cm}^{3}$ in $\mathrm{NB}$ ) and diminishing gains for increasing duration of early herbaceous vegetation control $\left(313.4 \times H-26.9 \times \mathrm{H}^{2} \mathrm{~cm}^{3}\right.$ in $\mathrm{ON} ; 405.1 \times H-60.1 \times \mathrm{H}^{2} \mathrm{~cm}^{3}$ in NB). The effects of herbaceous vegetation control were reduced in the absence of woody control to a greater extent in $\mathrm{ON}\left(-31.8 \times W H \mathrm{~cm}^{3}\right)$ than at the $\mathrm{NB}$ site $\left(-14.0 \times W \mathrm{~W} \mathrm{~cm}^{3}\right)$. Aspen and maple stem density, within the range tested, did not influence these outcomes $(p \geq 0.29)$. Two to four years of herbaceous vegetation control, coupled with woody control by year two, resulted in six- to more than 12 -fold increases in pine stem volume at the $\mathrm{ON}$ site, and four- to more than six-fold increases at the NB site. At age 6, we observed no increase in the volume of pine subjected to four years, compared to six years, of total competition suppression $(p \geq 0.45)$. Trees receiving two years of early herbaceous control plus second-season woody control exhibited $74 \%$ to $91 \%$ larger stem volume than those subjected to second-season broadcast release $(p \leq 0.10)$.

\section{Natural pine response}

Both shelterwood sites supported what might be considered excellent crops of naturally regenerated white pine at the end of the sixth growing season, averaging more than $90 \%$ stocking and 13000 stems per ha (Table 4). However, naturally regenerated seedling responses to the vegetation management treatments were not as clearly defined as those observed with the planted trees. For example, at the ON site, seedling diameter, height, and overall stem density, increased with vegetation management rigor and duration (e.g., $H$ linear, $p \leq 0.03$ ), but generally resulted in the opposite effect at the NB site. These differences are likely a reflection of differential priority being placed on the avoidance of natural regeneration at the time of directed foliar herbicide applications at the two sites. Glyphosate injury can reduce white pine survival and growth, as exemplified by statistics for the $\mathrm{ON}$ broadcast release treatment $(006000)(p<0.01)$, which reflect observed damage associated with direct overspray of natural regeneration seedlings. Nevertheless, the lowest stocking and density val- ues observed across both sites, despite herbicide impacts, were still above $70 \%$ and 3000 stems per ha; levels that most managers would consider adequate for the natural regeneration of these sites.

Likely due to their younger age, natural white pine regeneration exhibited reduced above-ground growth performance compared to the planted stock (Fig. 6). White pine natural regeneration took three to four years to attain average heights similar to those of planted pine in year 1. Regardless of tending regime, planted trees were more than twice as tall as natural trees during the early establishment period studied. In $\mathrm{ON}$, the growth trajectory of well tended trees (as exemplified by trees from $b b b b w w, b b w w w w$, and $h h b b w w$ plots) was similar, regardless of seedling origin, and reflected exponentialtype growth at year 6. In contrast, only well-tended, planted trees were exhibiting such growth at the NB site (a likely result of the herbicide effects on naturally regenerated seedlings mentioned above).

\section{Discussion}

This study was established to generate better understanding of how white pine regeneration in a shelterwood environment interacts with surrounding vegetation so that foresters might develop more consistent, effective, and scientifically-based vegetation management prescriptions. Our goal was not to compare and contrast vegetation management tools, but rather to identify vegetation conditions that appear to favour early growth and stem quality of white pine, such that these conditions may be recreated or emulated using one or more available tools.

\section{The shelterwood environment - a need for the right start}

Prior to installing this experiment at the ON site, the mature white and red pine-dominated stand had been marked for a uniform shelterwood regeneration cut, but subjected to harvest that resulted in many subordinate stems of spruce, balsam fir, maple, and aspen remaining standing due to their relatively low merchantable value. Unfortunately, this scenario is not uncommon in the northeast and can leave white pinedominated stands with understory light levels as low as $10 \%$, where seedling growth potential is greatly reduced and shadeinduced mortality is initiated (Logan 1966, Wendel and Smith 1990). Stands left in such a state reflect improper application of the uniform shelterwood method and require costly silvicultural interventions before regeneration can be successfully initiated.

A typical target for the regeneration cut of the uniform shelterwood system in white pine is to achieve overstory crown closure between 40\% and 50\% (OMNR 1998), resulting in understory light levels between $50 \%$ and $60 \%$ of full sunlight. The objective is to strike a balance between providing shade levels that are unfavourable to white pine weevils (de Groot et al.2005) and adequate light for germination and early establishment of natural regeneration (Wendel and Smith 1990), and near maximum height growth of natural or planted regeneration (Logan 1966, Wendel and Smith 1990). In practice, this may only be achieved by retaining a uniform distribution of dominant and co-dominant mature pine in the regeneration cut. If canopy distribution is not uniform, or if mid canopy and suppressed trees are left standing, the distribution of understory light will vary widely outside the target 
Table 4. Statistics for natural white pine regeneration at the end of the sixth growing season. Treatment codes are defined in Fig. 1. Treatment means have been averaged over the three hardwood densities studied.

\begin{tabular}{|c|c|c|c|c|c|c|c|c|c|}
\hline Site & Treatment Code & $\begin{array}{c}n \\
\text { plots }\end{array}$ & $\begin{array}{l}\text { Diameter } \\
(\mathbf{m m})\end{array}$ & $\begin{array}{c}\text { Height } \\
\text { (cm) }\end{array}$ & $\begin{array}{c}\text { Stem } \\
\text { volume } \\
\text { index } \\
\left(\mathrm{cm}^{3}\right)\end{array}$ & $\begin{array}{c}\text { White pine } \\
\text { stocking } \\
(\%)\end{array}$ & $\begin{array}{c}\text { White pine } \\
\text { (stems } \\
\text { per ha) }\end{array}$ & $\begin{array}{l}\text { Total pine } \\
\text { stocking } \\
(\%)\end{array}$ & $\begin{array}{c}\text { Total pine } \\
\text { density } \\
\text { (stems } \\
\text { per ha) }\end{array}$ \\
\hline \multirow[t]{22}{*}{$\mathrm{ON}$} & 000000 & 9 & 5 & 40 & 5 & 97 & 14667 & 98 & 25278 \\
\hline & $00000 w$ & 3 & 6 & 40 & 7 & 96 & 8500 & 98 & 11833 \\
\hline & $00 w w w w$ & 3 & 9 & 63 & 26 & 98 & 10333 & 98 & 15833 \\
\hline & $w w w w w w$ & 3 & 8 & 55 & 13 & 96 & 11667 & 100 & 27667 \\
\hline & hh0000 & 3 & 8 & 64 & 17 & 100 & 24000 & 100 & 42000 \\
\hline & hhhh00 & 9 & 8 & 62 & 17 & 99 & 20444 & 99 & 29056 \\
\hline & hho00w & 9 & 9 & 64 & 23 & 100 & 18833 & 100 & 29500 \\
\hline & $h h w w w w$ & 9 & 13 & 77 & 71 & 81 & 7111 & 94 & 15389 \\
\hline & hhhhOw & 3 & 8 & 47 & 14 & 98 & 14333 & 98 & 19667 \\
\hline & $h h b b w w$ & 3 & 13 & 78 & 60 & 83 & 7500 & 96 & 14500 \\
\hline & $b b w w w w$ & 3 & 14 & 100 & 65 & 100 & 24333 & 100 & 36667 \\
\hline & $b b b b w w$ & 3 & 20 & 123 & 164 & 100 & 22000 & 100 & 31000 \\
\hline & $b b b b b b$ & 3 & 12 & 83 & 49 & 100 & 17667 & 100 & 21667 \\
\hline & $00 b 000$ & 9 & 6 & 37 & 8 & 72 & 3389 & 94 & 10722 \\
\hline & mean & & 9 & 62 & 33.0 & 92 & 13903 & 98 & 22944 \\
\hline & RMSE & & 2 & 15 & 23 & 10 & 5632 & 6 & 9805 \\
\hline & $W$ linear & & 0.49 & 0.68 & 0.98 & 0.75 & 0.30 & 0.68 & 0.82 \\
\hline & $W$ quadratic & & 0.28 & 0.27 & 0.40 & 0.88 & 0.30 & 0.75 & 0.04 \\
\hline & $H$ linear & & $<0.01$ & $<0.01$ & 0.26 & 0.77 & 0.03 & 0.63 & 0.42 \\
\hline & $H$ quadratic & & 0.26 & 0.13 & 0.71 & 0.74 & 0.07 & 0.72 & 0.02 \\
\hline & Complete control & & $<0.01$ & $<0.01$ & $<0.01$ & 0.99 & 0.23 & 0.99 & 0.15 \\
\hline & Broadcast release & & $<0.01$ & $<0.01$ & $<0.01$ & 0.08 & 0.17 & 0.81 & 0.32 \\
\hline \multirow[t]{22}{*}{ NB } & 000000 & 9 & 12 & 75 & 66 & 100 & 17944 & 100 & 17944 \\
\hline & $00000 w$ & 3 & 10 & 58 & 63 & 94 & 15667 & 94 & 16000 \\
\hline & $00 w w w w$ & 3 & 17 & 97 & 182 & 90 & 11167 & 90 & 11167 \\
\hline & $w w w w w w$ & 3 & 20 & 111 & 185 & 100 & 15000 & 100 & 15000 \\
\hline & hh0000 & 3 & 11 & 55 & 60 & 100 & 9167 & 100 & 9167 \\
\hline & hhhh00 & 9 & 10 & 51 & 183 & 94 & 7500 & 94 & 7500 \\
\hline & hho00w & 9 & 10 & 45 & 39 & 93 & 12167 & 94 & 12222 \\
\hline & $h h w w w w$ & 9 & 10 & 42 & 21 & 99 & 15889 & 99 & 15889 \\
\hline & hhhhOw & 3 & 10 & 46 & 36 & 85 & 3167 & 85 & 3167 \\
\hline & $h h b b w w$ & 3 & 9 & 34 & 13 & 100 & 19667 & 100 & 19667 \\
\hline & $b b w w w w$ & 3 & 12 & 51 & 50 & 98 & 14500 & 98 & 14500 \\
\hline & $b b b b w w$ & 3 & 12 & 46 & 65 & 100 & 17333 & 100 & 17667 \\
\hline & $b b b b b b$ & 3 & 14 & 50 & 65 & 79 & 6333 & 79 & 6333 \\
\hline & $00 b 000$ & 9 & 11 & 56 & 56 & 99 & 14333 & 99 & 14333 \\
\hline & mean & & 11 & 56 & 75 & 96 & 13146 & 96 & 13181 \\
\hline & RMSE & & 4 & 21 & 175 & 7 & 7101 & 7 & 7098 \\
\hline & $W$ linear & & 0.10 & 0.39 & 0.66 & 0.90 & 0.82 & 0.90 & 0.85 \\
\hline & $W$ quadratic & & 0.59 & 0.50 & 0.84 & 0.03 & 0.33 & 0.03 & 0.34 \\
\hline & $H$ linear & & 0.32 & 0.01 & 0.16 & 0.07 & $>0.01$ & 0.07 & $<0.01$ \\
\hline & $H$ quadratic & & 0.89 & 0.55 & 0.56 & 0.49 & 0.43 & 0.49 & 0.43 \\
\hline & Complete control & & 0.42 & 0.82 & 0.99 & $<0.01$ & 0.06 & $<0.01$ & 0.06 \\
\hline & Broadcast release & & 0.34 & 0.19 & 0.68 & 0.99 & 0.64 & 0.99 & 0.64 \\
\hline
\end{tabular}

range, increasing the probability of patchy regeneration and inadequate stocking (Palik et al. 1997, Beaudet et al. 2010). More, mid-canopy and understory vegetation will impede access for silvicultural treatments including scarification, planting, and vegetation control, further exacerbating variability in regeneration success and stocking. Following thinning from below in the regeneration cut, the overstory canopies of our two study sites supported understory light conditions falling within the target range (50\% to $60 \%$ full sunlight), $\pm 5 \%$, more than $80 \%$ of the time (Fig. 3), and both sites offered clear access for subsequent silviculture (e.g., Fig. 2).
Vegetation management - the need to manage light and other resources

Given a shelterwood harvest that creates an understory environment conducive to white pine establishment, subsequent regeneration success will be achieved through the effective management of growing resources including sunlight, soil moisture, and nutrients. For the purpose of this discussion, we define regeneration success as full stocking to white pine seedlings that are growing at near maximum height potential. While the relative importance of these specific resources in the shelterwood environment is the subject of another paper 


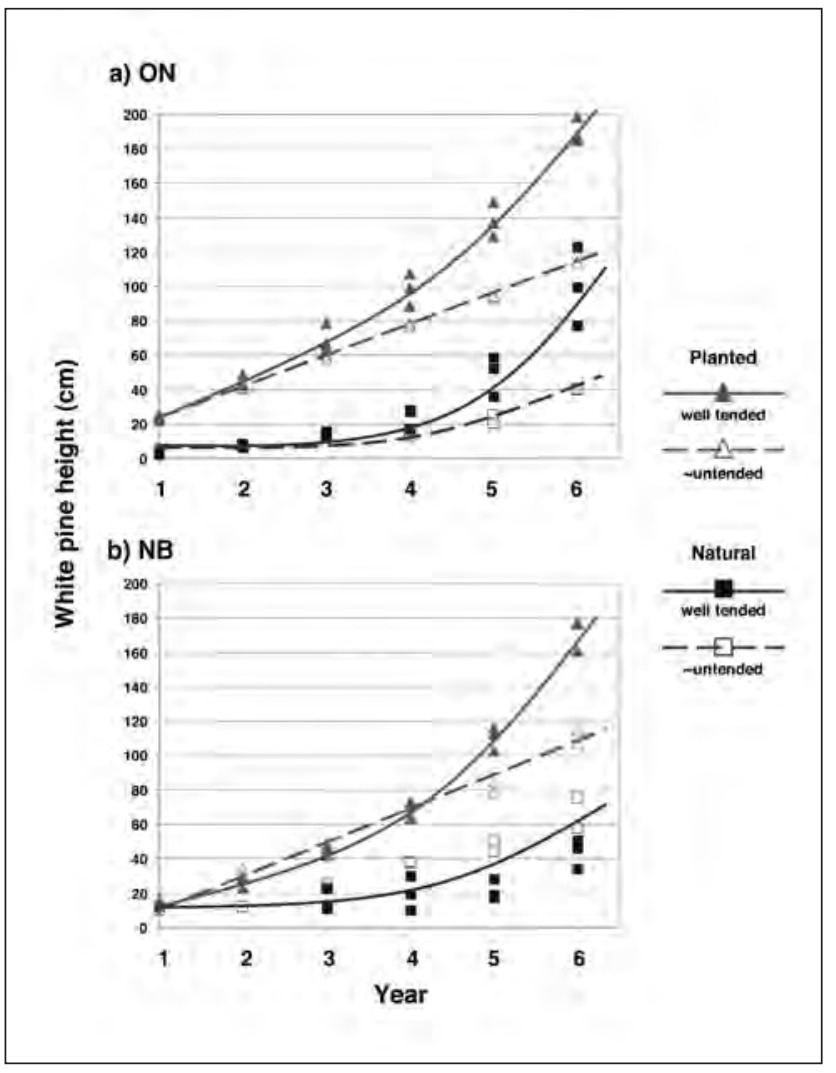

Fig. 6. Relative height growth performance of planted and naturally regenerated white pine at the ON (a) and NB (b) sites. Trees grouped as "well tended" include those from treatments bbbbww, bbwwww, and hhbbww; trees grouped as comparatively "untended" include those from treatments 000000 and $00000 w$ (see Fig. 1 for code definitions).

(Parker et al. in prep.), our empirical evidence suggests that competition for all three resources may limit regeneration success in a uniform shelterwood and should be addressed in an effective vegetation management strategy.

In a shelterwood, the management of light should be given high priority by default, simply because the very narrow target range for understory light levels is situated just above the known threshold for maximum white pine growth (45\%; Logan 1966). Fast-growing deciduous tall shrubs and tree species have high height dominance potential and, if not controlled, will competitively exclude conifers over time (Newton 1973). However, in the short term, these deciduous woody competitors in the uniform shelterwood environment will rapidly produce excess shade for regenerating pine. At the ON site, for example, undisturbed aspen and red maple regeneration formed nearly $50 \%$ cover above planted pine after six growing seasons. This deciduous woody growth and development was equal to or slightly greater than that observed over a similar period, on a similar site, in a clearcut condition (Pitt et al. 2009), suggesting that the shelterwood, by itself, offered no relief from this type of competition. If the sixth year size of the planted pine in the most intensively weeded plots (bbbbww) were considered to be representative of near-maximum early growth potential, the control of woody competition alone captured approximately $70 \%$ of seedling height growth potential and $48 \%$ of stem diameter growth potential (Table 2).
Similarly, herbaceous vegetation, bracken fern (Pteridium aquilinum L.) in particular, can overtop and shade young pine and produce substantive early cover (in excess of 50\%) in untended plots (Parker et al. 2009, Gaudio et al. 2011). Compared to woody-only control, the early control of herbaceous vegetation captured just as much, if not more, of the height growth potential of planted pine ( $70 \%$ in ON, $90 \%$ in NB; Table 2 ) and $44 \%$ to $68 \%$ of the stem diameter growth potential.

Not until both woody and herbaceous vegetation control was conducted, did we observe planted pine reaching their full growth potential (Table 2; Fig. 4 to Fig. 6). This suggests that fairly serious competition for more than just light was present beneath the two uniform shelterwoods studied. It is well understood that seedling height growth typically takes priority over diameter growth in photosynthate allocation (Larcher 1995). In analogy, one might imagine the stresses of competition as a force exerting pressure on the physical dimensions of a seedling: as competitive pressure is gradually increased from 0 , seedling diameter is first reduced, until a point where diminishing photosynthate levels are redirected to maintain height growth. As competitive stress increases, height growth suffers; a sign indicating substantial stress, often achieved under low light conditions (Wagner 2000). As competitive pressure is further increased, height growth ceases and the seedling finally dies. Competition levels at the two sites had not, by year 6 , reached the point where mortality was a factor $(p \geq 0.07)$; however, the fact that height growth was not maximized by the control of either woody or herbaceous competition alone suggests that both vegetation groups were exerting very high levels of competition for resources beyond just light in the shelterwood understory. Where bracken fern cover was high, plots also exhibited signs of snow-press injury on both planted and natural pine, suggesting that competition for aboveground space was also present.

These results contrast somewhat with those observed in a clearcut environment (Pitt et al. 2009), where damage caused by white pine weevil reduced the early height performance of planted pine wherever woody vegetation (and associated overhead shade) was removed. There, the early suppression of herbaceous vegetation alone allowed pine to realize maximum height growth potential, yet some woody vegetation control was also required for near-maximum diameter growth. Thus, although light is not limiting in the clearcut environment, optimum vegetation management there involves a delicate balance between allowing some woody overtopping/shading to minimize weevil impacts, and reducing competition from herbaceous and woody vegetation to free up adequate soil moisture and nutrients for acceptable diameter growth (Parker et al. 2009, 2010; Wetzel and Burgess 2001). Subsequent periodic intervention(s) would likely be required to maintain the balance of pine and hardwood in long-term stand dynamics. In the uniform shelterwood environment, our data suggest that vegetation management must be targeted at the immediate removal of woody vegetation and the provision of a relatively herbaceous-free period for the first two to four years to maximize the availability of sunlight, soil moisture, and nutrients.

\section{Natural regeneration opportunities}

The design and execution of this experiment was necessarily focused on the performance of planted white pine. However, natural regeneration is often an objective of the uniform shel- 
terwood system-planting only being used to guarantee immediate regeneration establishment where adequate seed rain cannot be relied upon or is not expected.

Chain scarification at both of the sites used in this study produced highly receptive seedbeds for natural regeneration that were available for germination for at least four years, as evidenced by the new germinants found in our assessment plots throughout this period. It is therefore likely that the regeneration achieved in these studies (Table 4) originated from multiple seed years. There is also some evidence that herbaceous vegetation control treatments, and minimal herbaceous litter inputs to exposed mineral soil seedbeds, contributed to the availability and/or longevity of these germination sites (e.g., increased white pine density in $\mathrm{ON} ; p=$ 0.03 ), but this effect was variably masked by glyphosate injury.

In the northeast, mechanical site preparation and glyphosate are the only viable tools available for achieving herbaceous vegetation control; unfortunately both are somewhat incompatible with established white pine seedlings unless applied in a (more costly) selective fashion. This, coupled with the need for the early reduction of both woody and herbaceous competition identified above, suggests that silvicultural treatments be, wherever possible, conducted as site preparation, in advance of seedling establishment. If high densities of regeneration can be achieved (e.g., full stocking to $>3000 \mathrm{sph}$ ), then some collateral losses associated with subsequent silvicultural treatments may be tolerated (if not desired in view of reducing future precommercial thinning costs).

Although slightly less clearly defined than the planted tree growth responses in our study, natural pine regeneration responded strongly and positively to early woody and herbaceous competition control (Fig. 6). In the absence of vegetation management, it is very likely that these sites, despite proper regeneration cuts and site preparation, would produce hardwood-leading mixedwood stands. There are ample operational examples of such stand dynamics across the northeast, underscoring not only the need for vegetation management, but the need for early vegetation management targeted at both woody and herbaceous competition. Clearly, natural regeneration and partial cutting systems do not absolve managers of vegetation management responsibility.

Given that establishment of natural regeneration takes place over a period of two to four years or more, and the fact that it takes several years for a germinant to achieve seedling status, it is not surprising that planted trees have a significant early growth advantage over naturally regenerating pine in a uniform shelterwood scenario (Fig. 6). That these growth differences continue over time remains to be seen; however, in the spirit of capturing growing resources freed up by scarification/site preparation and early vegetation management treatments, planted trees hold an obvious advantage over natural regeneration in terms of a manager's desire to guarantee the successful regeneration of a site within a fixed period of time. Planting also offers the opportunity to introduce genetically improved stock, where available, and species such as spruce that, in mixture with pine, offer more valuable commercial thinning opportunities than pure pine in long-term crop plans. However, the added cost of planting trees is significant and, in all but the most intensive silvicultural regimes, should be used in situations where natural regeneration is less certain. Our data suggest that low-density plantings, augmented with natural regeneration, would be a good strategy.

\section{Operational implementation}

We draw upon the results from this experiment, the literature, and our experience to offer the following operational recommendations for the successful establishment of white pine regeneration using the uniform shelterwood method. In our opinion, success depends on four key requirements being met:

1) a properly implemented regeneration cut with trees of suppressed and intermediate crown classes removed, and dominant and codominant trees spaced, in a manner that results in uniform distribution of understory light ranging between $50 \%$ and $60 \%$ of full sunlight;

2) scarification, timed with a good seed year, that provides uniform distribution of microsites receptive to white pine germination and/or site preparation that permits planter access to microsites consistent with a target planting density;

3) early reduction in competition from woody and herbaceous vegetation; and

4) maintenance of a relatively competition-free period for the first two to four years.

How these requirements are met is a matter of blending available tools within local legislation.

Guidelines for the regeneration cut are well established and options/implements for scarification and site preparation have been covered elsewhere (Lancaster and Leak 1978, Hannah 1988, OMNR 1998). It is our experience that chains (Fig. 2) offer one of the least expensive and most effective implements for scarification in white pine shelterwoods. Where emphasis is placed on the creation of planting microsites, as opposed to seedbed preparation, disc trenchers or small bulldozers are favoured by some practitioners, but chains may still do an effective job, especially on sites where wood utilization is maximized and the abundance of large slash minimized. We note that it is the timing of scarification, not the regeneration cut, that one should synchronize with a good seed year for maximum regeneration potential.

Scarification or site preparation can positively or negatively contribute to the early reduction of competition from woody and herbaceous vegetation, depending on stand conditions at the time of the regeneration cut. If, for example, deciduous woody vegetation is well developed in the understory, mechanical disturbance during harvest, scarification, or site preparation at times of the year other than early to midJuly, when carbohydrate reserves in root systems are lowest, can result in significant root suckering following disturbance (Kays and Canham 1991). The same result will follow direct, non-chemical means of removing these plants, such as with brushsaws or mowers (Bell et al. 1999). Alternatively, a broadcast application with glyphosate, after harvest but before scarification or site preparation, may effectively reduce the amount of woody competition following these activities.

Herbaceous vegetation present on the site will temporarily be removed during scarification/site preparation activity, but since many species originate from seed stored in the soil, they can almost always be expected to recover rapidly following these mechanical treatments. In Canada, tools for controlling herbaceous vegetation on the relatively coarse-textured soils 
that characterize most white pine sites are extremely limited (Thompson and Pitt 2003). Glyphosate is the only registered herbicide available for this purpose and, at the time of writing, there were no practical alternatives available to those who choose not to use herbicides. Given one's ability to use glyphosate, the most cost-effective strategy commonly used by some foresters in the northeast is to time regeneration harvest and/or scarification/site preparation during early to midJuly (to minimize woody suckering), followed by a broadcast application of glyphosate in late August of the following year. This one-growing season lag will allow the regeneration of woody and herbaceous competitors, offering their maximum exposure to herbicide, while they are still relatively small in size and cover. Some early pine regeneration may be lost in this sequence of events, but the ensuing competition-free period should provide an excellent environment for germination or the establishment of seedlings planted at this time.

One may be tempted to avoid the early herbicide treatment of woody and herbaceous competition in the above-recommended scenario, instead opting to delay this treatment for two growing seasons after planting or natural regeneration establishment. Our results emphasize growth advantages in early competition reduction and suggest that there may be considerable penalty in such a delay. For example, planting, followed by broadcast glyphosate release at the end of the second growing season resulted in trees that were $15 \%$ to $18 \%$ shorter in height and $74 \%$ to $91 \%$ lesser in stem volume than trees similarly treated early (00b000 vs. $h h w w w w$; Table 2$)$.

The maintenance of two to four years of relatively competition-free conditions post establishment can be problematic without subsequent intervention, since many white pine shelterwoods are situated on highly productive sites that are prone to rapid growth and development of both woody and herbaceous vegetation. Given the approach recommended above, subsequent herbicide release may be required between the second and fourth growing season to maintain maximum growth of the white pine regeneration. Broadcast application of glyphosate may result in some herbicide injury to the pine. However, if target vegetation has been kept in reasonable check by preceding silvicultural treatments, relatively reduced herbicide rates may be used and injury kept within tolerable levels, given the seedling densities present. Methods of herbicide application vary with the availability of local equipment, ranging from skidder-mounted air-blast sprayers to fixedand rotary-winged aircraft (OMNR 1998). Recent research efforts have focused on determining the best aerial delivery systems for obtaining overstory canopy penetration and maximizing understory coverage. Ground application methods, such as backpack-directed foliar applications, have logical fit in small stands, where the mobilization of larger equipment may be impractical.

Ultimately, the cumulative cost of the silvicultural interventions required to successfully regenerate white pine using the uniform shelterwood system must be weighed against the stand- and forest-level advantages of initiating overstory removal cuts at the earliest possible times. The overall valuation of silviculture in the maintenance of social, environmental, and economic values related to this important species represents an important research need.

\section{Acknowledgements}

This research would not be possible without the generous financial backing and partnerships offered by the following: Canadian Ecology Centre - Forestry Research Partnership (Tembec, Canadian Forest Service, Ontario Ministry of Natural Resources); Living Legacy Trust; Canada Foundation for Innovation; Enhanced Forest Productivity Science Program Forestry Futures Trust Ontario; Ontario Innovation Trust Fund; Monsanto Canada Inc., Dow AgroSciences Canada Inc.; Collège Boréal; Domtar Corporation; Nipissing Forest Resource Management Inc.; J.D. Irving Limited; Forest Protection Limited; SERG International; Upper Lakes Environmental Research Network; and the U.S. Forest Service. Wayne Bell and Michael Irvine were instrumental in facilitating OMNR funding and support. The research team is greatly indebted to field staff, too numerous to mention here, without whose care and effort this study would not be possible. Finally, two anonymous reviewers provided thoughtful suggestions for improving this manuscript.

\section{References}

Beaudet, M., B.D. Harvey, C. Messier, K.D. Coates, J. Poulin, D.D. Kneeshaw, S. Brais and Y. Bergeron. 2010. Managing understory light conditions in boreal mixedwoods through variation in the intensity and spatial pattern of harvest: A modelling approach. For. Ecol. Manage. 261: 84-94.

Bell F.W., D.G., Pitt, A. Morneault and S. Pickering. 1999. Response of immature trembling aspen to season and height of cut. North. J. Appl. For. 16: 108-114.

Burgess, D. and S. Wetzel. 2000. Nutrient availability and regeneration response after partial cutting and site preparation in eastern white pine. For. Ecol. Manage. 138: 249-261.

Burgess, D. and S. Wetzel. 2002. Recruitment and early growth of eastern white pine (Pinus strobus) regeneration after partial cutting and site preparation. Forestry 75: 419-423.

Chambers, B. 1991. Understorey vegetation response to three silvicultural treatments in the white pine working group. Central Ontario Forest Tech. Dev. Unit. Tech. Rep. No. 15. 52 p.

Colpitts, M.C., S.H. Fahmy, J.E. MacDougall, T.T. Ng, B.G. McInnis and V.F. Zelazny. 1995. Forest Soils of New Brunswick. New Brunswick Department of Natural Resources and Energy. Fredericton, NB. 51 p.

de Groot, P., A.A. Hopkin and R.J. Sajan. 2005. Silvicultural techniques and guidelines for the management of major insects and diseases of spruce, pine, and aspen in eastern Canada. Nat. Res. Can., Can. For. Serv., Great Lakes Forestry Centre, Sault Ste. Marie, ON P6A 2E5. 65 p.

Draper, N.R. and H. Smith. 1998. Applied Regression Analysis. Third Ed. John Wiley \& Sons, New York.

Frelich, L.E. 2002. Forest dynamics and disturbance regimes. Cambridge University Press, Cambridge. 266 p.

Gaudio, N., P. Balandier, Y. Dumas and C. Ginisty. 2011. Growth and morphology of three forest understorey species (Calluna vulgaris, Molina caerulea and Pteridium aquilinum) according to light availability. For. Ecol. Manage. 261: 489-498.

Hannah, P.R. 1988. The shelterwood method in northeastern forest types: a literature review. North. J. Appl. For. 5: 70-77.

Hibbs, D.E. 1982. White pine in the transition hardwood forest. Can. J. Botany 60: 2046-2053.

Hosie, R.C. 1953. Forest regeneration in Ontario. Research Council of Ontario, University of Toronto Press, Toronto, ON. Forestry Bulletin. No. 2. 134 p.

Kays, J.S. and C.D. Canham. 1991. Effects of time and frequency of cutting on hardwood root reserves and sprout growth. For. Sci. 37: 524-539. 
Krueger, J.A. and K.J. Puettmann. 2004. Growth and injury patterns of eastern white pine (Pinus strobus L.) seedlings as affected by hardwood overstory density and weeding treatments. North. J. Appl. For. 21(2): 61-68.

Lancaster, K.F. and W.B. Leak. 1978. A silvicultural guide for white pine in the Northeast. USDA For. Serv., Gen. Tech. Rep. NE-41.

Larcher, W. 1995. Physiological plant ecology: ecophysiology and stress physiology of functional groups. $3^{\text {rd }}$ ed. Springer, Berlin. 506 p. Logan, K.T., 1966. Growth of tree seedlings as affected by light intensity. II. Red pine, white pine, jack pine, and eastern larch. Department of Forestry, Ottawa. Publication 1160. 19 p.

Loucks, O.L. 1962. A forest classification for the Maritime Provinces. Proc. Nova Scotian Inst. for the Maritime Provinces. Vol. 25. $167 \mathrm{p}$

Major, J.E., A. Mosseler, D.C. Barsi, A. Clouthier and M. Campbell. 2009. Impact of three silvicultural treatments on weevil incidence, growth, phenology, and branch-level dynamics of Pinus strobus from large and small populations. Can. J. For. Res. 39: 12-25. Messier, C. and P. Puttonen. 1995. Spatial and temporal variations in the light environment of developing Scots pine stands: the basis for a quick and efficient method of characterizing light. Can. J. For. Res. 25: 343-347.

Montgomery, D.C. 2001. Design and Analysis of Experiments. Fifth Ed. John Wiley \& Sons, New York.

Myketa, D. and M.S. McLaughlan. 1996. The shelterwood silvicultural system as related to vegetation management. Ont. Min. Nat. Res., Northwest Science and Technology. TN-35. 10 p.

Newton, M. 1973. Forest rehabilitation in North America: some simplifications. J. For. 71: 159-162.

[OMNR] Ontario Ministry of Natural Resources. 1998. A silvicultural guide for the Great Lakes - St. Lawrence conifer forest in Ontario. Ont. Min. Nat. Res., Queen's Printer for Ontario. Toronto. $424 \mathrm{p}$.

2009. Ecological Land Classification Field Manual - Operational Draft, April 20th, 2009. Ecological Land Classification Working Group, Ontario. Unpublished manual.

Palik, B.J. R.J. Mitchell, G. Houseal and N. Pederson. 1997. Effects of canopy structure on resource availability and seedling responses in a longleaf pine ecosystem. Can. J. For. Res. 27: 1458-1464.

Parker, W.C., D.G. Pitt and A.E. Morneault. 2009. Influence of woody and herbaceous competition on microclimate and growth of eastern white pine (Pinus strobus L.) seedlings planted in a central Ontario clearcut. For. Ecol. Manage. 258: 2013-2025.

Parker, W.C., D.G. Pitt and A.E. Morneault. 2010. Influence of woody and herbaceous control on leaf gas exchange, water status, and nutrient relations of eastern white pine (Pinus strobus L.) seedlings planted in a central Ontario clearcut. For. Ecol. Manage. 260: 2012-2022.
Parker, W.C., D.G. Pitt and A.E. Morneault. (in preparation). The influence of herbaceous and woody vegetation control on the microclimate, gas exchange, water status, and foliar nutrient status of white pine seedlings planted in a shelterwood. Ann. For. Sci.

Pitt, D.G., A. Morneault, W. C. Parker, A. Stinson and L. Lanteigne. 2009. The effects of herbaceous and woody competition on planted white pine in a clearcut site. For. Ecol. Manage. 257: 1281-1291.

Puettmann, K.J. and M.R. Saunders. 2001. Patterns of growth compensation in eastern white pine (Pinus strobus L.): the influence of herbivory intensity and competitive environments. Oecologia 129: 376-384.

Rowe, J.S. 1972. Forest Regions of Canada. Can. For. Ser., Ottawa. Publ. No. 1300.

Saunders, M.R. and K.J. Puettmann. 1999. Effects of overstory and understory competition and simulated herbivory on growth and survival of white pine seedlings. Can. J. For. Res. 29: 536-546.

SAS Institute Inc., 2004. SAS OnlineDoc ${ }^{\oplus}$ 9.1.3. SAS Institute Inc., Cary, NC.

Shirley, H.L. 1945. Reproduction of upland conifers in the Lakes States as affected by root competition and light. Am. Mid. Nat. 33: 537-612.

Smidt, M.F. and K.J. Puettmann. 1998. Overstory and understorey competition affect underplanted eastern white pine. For. Ecol. Manage. 105: 137-150.

Stiell, W.M. 1985. Silviculture of eastern white pine. Proceedings of the Entomological Society of Ontario 116 (Suppl.): 95-107.

Thompson, D.G. and D.G. Pitt. 2003. A review of Canadian forest vegetation management research and practice. Ann. For. Sci. 60: 559-572.

Wagner, R.G. 2000. Competition and critical-period thresholds for vegetation management decisions in young conifer stands. For. Chron. 76(6): 961-968.

Wendel, G.W. and H.C. Smith. 1990. Pinus strobus L: Eastern White Pine. In R.M. Burns and B.H. Honkala (tech. coords.). Silvics of North America. Vol. 1. Conifers. pp. 476-488. USDA Agric. Handbk. No. 654. Washington, DC.

Wetzel, S. and D. Burgess. 2001. Understorey environment and vegetation response after partial cutting and site preparation in Pinus strobus L. stands. For. Ecol. Manage. 151: 43-59. 